Marquette University

e-Publications@Marquette

Accounting Faculty Research and Publications

Accounting, Department of

$1-1-2009$

\title{
International Perception of Corruption
}

Bina Menon

Marquette University

Michael D. Akers

Marquette University, michael.akers@marquette.edu

Published version. Review of Business Information Systems, Vol. 13, No. 1 (First Quarter, 2009): 25-39. DOI. (C) 2009 The Clute Institute. Used with permission. 


\title{
International Perception Of Corruption
}

Bina Menon, Marquette University, USA

Dr. Michael D. Akers, Marquette University, USA

\begin{abstract}
The discussion of corruption and bribery in most auditing textbooks focuses only on the Foreign Corrupt Practices Act which is an amendment to the Securities Exchange Act of 1934. As the US moves toward the implementation of International Financial Reporting Standards (IFRS) and international auditing standards, an understanding of international legislation pertaining to corruption and the perception of corruption in specific countries are important. This paper provides an overview of the Foreign Corrupt Practices Act (FCPA) and the Organization for Economic Co-operation and Development (OECD) Anti-bribery Convention. While prior literature has discussed the impact of both the FCPA and OECD on corruption and bribery, this paper extends prior literature by providing an update on phase II the OECD and examines how the OECD countries are viewed in comparison to non OECD countries using five publicly available measures of corruption. Corruption indices that can be purchased are also identified. Our findings show that the highest ranked OECD countries across the corruption indices are Denmark, Finland and New Zealand while the lowest ranked OECD countries are Argentina, Brazil, Mexico and Turkey. One non-OECD country, Singapore, consistently received high scores (low corruption) across the indices.
\end{abstract}

\section{INTRODUCTION}

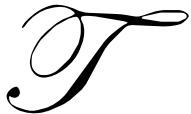

he Foreign Corrupt Practices Act (FCPA) of 1977 continues to remain the cornerstone for antibribery legislation worldwide. The Organization for Economic Co-operation and Development (OECD) Anti-bribery Convention, inspired by the US FCPA, has attempted to address corruption and bribery on a global basis mandating uniform legislative implementation from its member countries. While the OECD itself monitors the implementation and performance amongst its members, several independent agencies have also attempted to measure corruption and bribery on a per-country basis. A study of these rankings is not only useful for comparative evaluation amongst members and non-members but it also provides valuable insight regarding anti-corruption measures within each country.

Globally, in an attempt to standardize financial reporting, several countries have now mandated the adoption of International Financial Reporting Standards for public companies. Even within the US, under the Norwalk Agreement (http://www.fasb.org/news/memorandum.pdf) discussions between Financial Accounting Standards Board and International Accounting Standards Board have called for a convergence between the US Generally Accepted Accounting Practices and IFRS. These efforts will help standardize not only financial reporting but will also help address issues regarding bribery. However, while most auditing textbooks provide a brief overview of the provisions of the US FCPA as it pertains to auditor responsibilities, few provide a comprehensive analysis of the anti-bribery provisions itself or an understanding of anti-corruption legislation and its enforcement globally.

Similarly, since the adoption of the OECD Convention, there have been publications that have focused on the impact of the OECD convention on member countries, auditors and on international business (Apke, 2001). Some publications have discussed the evolution of the OECD, the OECD Convention and the two quantitative rankings by Transparency International (TI). Further, they have analyzed the impact of the OECD Convention provisions, notably the accounting requirements as detailed in Article 8. This includes standard setting for disclosures and maintenance of books and records as well as an auditor's assessment of a company's inherent risk and control environment, both of which are greatly influenced by a country's anti-corruption ratings (Pacini et al, 2002). This article is especially relevant in light of the Statement of Accounting Standards (SAS) No. 99 issued in 
2002 by the Accounting Standards Board. While SAS 99 superseded SAS 82, the statement provided directives for identification and assessment of fraud including exercise of professional skepticism, obtaining information, identifying risks related to material misstatements, assessing the identified risks, responding and evaluating audit evidence and finally communicating and documenting such findings.

Also, some articles have provided a regional overview of corruption and weaknesses in implementation (Bennet, 2008) while some have detailed the progress of the FCPA within the US (Santangelo et al, 2007). However, we have yet to come across a publication comparing the various anti-corruption rankings for OECD member and non-member countries.

The first section of the paper provides an overview of the US FCPA which was passed in 1977 and the subsequent adoption of similar laws by member countries under the auspices of the OECD. Five publicly available international corruption indices, as well as the identification of corruption indices available that can be purchased, are examined in section two of the paper followed by a comparison of the performance of OECD member and nonmember countries against those of non-affiliated countries. Section three of the paper examines Phase II of the OECD which focuses on the progress made within member countries since the introduction of such legislation and specifically the factors that require attention. The final section provides concluding comments.

\section{LEGISLATIVE HISTORY}

\section{Foreign Corrupt Practices Act}

With globalization and an increasing number of domestic companies establishing trading parmers and business ventures overseas, the requirement for a transparent and ethical global business environment had become essential. In a study conducted by the Securities and Exchange Commission in the mid-1970's, nearly 400 companies including 117 of the Fortune 500 companies then admitted to using corporate funds to pay out foreign government officials, politicians, and political parties in order to secure favorable action. In absolute dollar amounts this amounted to nearly $\$ 300$ million (Gerlach, Paul V. - Testimony on September 10, 1998: The International AntiBribery and Fair Competition Act of 1988 http://www.sec.gov/news/testimony/testarchive/1998/tsty1 198.txt). While domestic bribery had always been considered illegal, foreign bribes were not. Hence, in an attempt to resurrect public confidence in the integrity of the American business system and to uphold the image of corporate America, Congress began the unprecedented task of introducing the foreign anti-bribery legislation in the United States.

Congress introduced two bills to address this need for transparency. One was the 'Foreign Corrupt Practices and Domestic and Foreign Investment Improved Disclosure Act of 1977' while the second was the 'Unlawful Corporate Payments Act of 1977', both introduced in the $1^{\text {st }}$ session of the $95^{\text {th }}$ Congress. (Unlawful Corporate Payments Act of 1977: $95^{\text {th }}$ Congress, $1^{\text {st }}$ Session, Report No. 95-640). While both legislations attempted to amend the Securities Exchange Act of 1934, one was introduced in the Senate while the other in the House of Representatives.

The Unlawful Corporate Payments Act, proposed in the House of Representatives in September 1977, proposed to enact a new section - section 30A, within the Securities Act of 1934. This was aimed primarily at making it unlawful for an issuer of securities or an issuer required to file reports to make certain payments to foreign officials and other foreign persons. (Unlawful Corporate Payments Act of 1977: $95^{\text {th }}$ Congress, $1^{\text {st }}$ Session, Report No. 95-640). The Act was designed to prohibit bribing foreign officials, foreign political parties and candidates for foreign political office. Of the two approaches considered for countering bribery of foreign officials, the first was to legalize the payments by requiring public disclosure and imposing criminal penalties for failure to do so. While the second approach, which was eventually agreed-upon, was to outlaw these payoffs with criminal sanctions. Additionally, it recommended that the Securities and Exchange Commission continue to retain investigative jurisdiction, on companies within its purview, with respect to prohibitions against corrupt payments.

The Foreign Corrupt Practices and Domestic and Foreign Investment Improved Disclosure Act of 1977 was introduced in the Senate and was also aimed at amending the Securities Exchange Act of 1934. It comprised of three subsections, the first two sections emphasized transparency, requiring domestic companies to maintain strict 
accounting standards and management control over their assets as well as prohibiting the falsification of accounting records, while the third section proposed criminalization of bribery of foreign officials.

In December 1977, the Foreign Corrupt Practices Act, a substitute for the Senate bill and the House amendment was approved by both houses of Congress. (Foreign Comupt Practices, $1977-95^{\text {th }}$ Congress, $1^{\text {st }}$ Session, Report No. 94-831) It amended several sections of the Securities and Exchange Act of 1934 including sections 12,13 and 15 while at the same time adding new sections to the Act as well as a new provision in the criminal code. The Act incorporated the provisions of the previous bills, it contained the anti- bribery provisions with respect to foreign officials as well as bookkeeping provisions requiring adequate amount of internal control for domestic companies. It recommended joint enforcement by the Securities and Exchange Commission and the United States Department of Justice.

In 1988, Congress enacted several amendments to the FCPA. The Foreign Corrupt Practices Act Amendments of 1988 was signed into law as Title V of the Omnibus Trade and Competitiveness Act of 1988. (Seitzinger,1999). While the amendments maintained the three main provisions of the Act, it explicitly excluded bribery provisions for facilitating payments for 'routine governmental action'. It also provided affirmative defenses against alleged violations of the FCPA. In addition, it increased the penalties imposed on violations.

Since the United States was amongst the first to introduce a foreign official anti-bribery legislation, concerns existed about the impact on the global competitiveness of domestic companies. Most countries, including domestic trading partners, did not have an anti-bribery legislation; bribes paid to foreign public officials qualified as business expenses and were consequently tax deductible. Thus the domestic business community believed that it operated at a global disadvantage since not only were deductions disallowed, it was penalized for making such payments. Loss in international contracts for US companies was estimated at $\$ 30$ billion over seven years (Foreign Press Center Briefing, June 29, 2001 - http://www.fpc.state.gov/fpc/7490.htm). In an attempt to overcome this disparity in international standards and to help establish good corporate governance, the US encouraged some of its leading trade partners to enact legislation similar to the FCPA.

\section{The Organization For Economic Co-Operation And Development}

The United States helped establish the Organization for Economic Co-operation and Development, a multilateral organization established in 1961 and which comprised of 29 established members, including the U.S., and 5 non-members. The organization was originally formed in 1947 as the Organisation for European Economic Co-operation (OEEC) to administer American and Canadian aid for the reconstruction of Europe after World War II. Thus the OECD superseded the OEEC and was aimed at promoting policies for assisting economic expansion in countries and enabling ease of trade on a multilateral, non-discriminatory basis. At the initiative of the United States, the OECD Convention on Combating Bribery of Foreign Public Officials in International Business Transactions was introduced $^{6}$ : it was signed in 1997 and ratified in 1998. As a written international agreement, the OECD AntiBribery Convention set forth the basic model elements of a foreign corrupt practices statute that each signatory country agreed to enact into law soon after each country's ratification of the Convention. (International Agreements: http://www.fcpaenforcement.com/documents/document detail.asp?ID=713\&PAGE=4). The Convention aimed at curbing international bribery and promoting sound business ethics.

The provisions introduced by the Convention addressed 13 categories. While Article 1 addressed the primary issue of bribing a foreign public official, Articles 2 through 6 provided guidance with respect to the responsibility of legal persons, sanctions, jurisdiction and enforcement. Similar to the U.S. FCPA, additional provisions of the Convention addressed requirements for monitoring money laundering and a corporation's requirement for strict internal controls and independent external auditing. Finally, it also recommended the establishment of an independent agency for monitoring implementation and for further follow-up. Accordingly, a Working Group was set up to help monitor compliance with the Convention as well as to measure progress in implementation of Convention provisions amongst member countries. The monitoring process was subdivided into two phases, Phase 1 would involve an assessment of a country's conformity with anti-bribery laws domestically while Phase 2 sought to address compliance with the foreign public official anti-bribery laws. 
Presently, 37 countries have ratified the OECD Anti-Bribery Convention. While 30 of these are OECD members, seven are non-OECD countries. These non-members are participants in the Working Group on Bribery and have willingly adopted the ratification of the Convention. In 2007, South Africa became the $37^{\text {th }}$ country and the $7^{\text {th }}$ non-member and the most recent signatory of the Convention. The 37 countries that have ratified the convention are shown in Table 1.

TABLE 1

OECD ANTI BRIBERY CONVENTION - MEMBER AND NON-MEMBER COUNTRIES

\begin{tabular}{|c|}
\hline COUNTRY \\
\hline Member Countries \\
\hline Australia \\
\hline Austria \\
\hline Belgium \\
\hline Canada \\
\hline Czech Republic \\
\hline Denmark \\
\hline Finland \\
\hline France \\
\hline Germany \\
\hline Greece \\
\hline Hungary \\
\hline Iceland \\
\hline Ireland \\
\hline Italy \\
\hline Japan \\
\hline Luxembourg \\
\hline Mexico \\
\hline Netherlands \\
\hline New Zealand \\
\hline Norway \\
\hline Poland \\
\hline Portugal \\
\hline Slovakia \\
\hline South Korea \\
\hline Spain \\
\hline Sweden \\
\hline Switzerland \\
\hline Turkey \\
\hline United Kingdom \\
\hline USA \\
\hline \\
\hline
\end{tabular}
COUNTRY Non-Member Countries

\begin{tabular}{|c|}
\hline Non-Member Countries \\
\hline Argentina \\
\hline Brazil \\
\hline Bulgaria \\
\hline Chile \\
\hline Estonia \\
\hline Slovenia \\
\hline South Africa \\
\hline
\end{tabular}

In keeping with the provisions of the OECD Anti-Bribery Convention, the US initiated the International Anti-Bribery and Fair Competition Act of 1998. This Act amended the existing FCPA so as to conform to the requirements and implement the OECD Convention. (International Anti-Bribery Act of 1998, Amendments: http://www.justice.gov/criminal/fraud/fcpa/history/1998/amends/leghistory.html).

The Act expanded the FCPA's scope to include payments made to secure any improper advantage. While the FCPA related to only entities with securities registered under the 1934 Securities Exchange Act and domestic entities, the amendment expanded the FCPA's coverage to include all foreign persons guilty of offering a foreign bribe while in the United States. It expanded the FCPA's definition of public officials to include officials of public international organizations. Further, it amended the FCPA to eliminate any disparity in penalties applicable to domestic and foreign nationals and subjected all employees or agents of U.S. businesses to both civil and criminal penalties. 


\section{CORRUPTION INDICES}

Corruption and bribery continue to remain serious challenges to effective free market rade globally. Effective enactment of anti-bribery and anti-corruption initiatives hence continues to remain paramount. Several independent agencies have attempted to measure corruption and bribery worldwide. While the methodology employed by each agency in rating these corruption parameters differs, a comparative analysis of findings from multiple sources provides a generalized overview as to the effectiveness of measures undertaken within the OECD countries. Most indices use multiple data sources, with some using as many as 33 data sources. As a result, a variation in data from one data source or a change in methodology or confidence intervals used for data aggregation can lead to changes in the rankings. Hence, a yearly comparison of scores may not yield accurate results.

Some of the prominent anti-corruption and anti-bribery rankings available to the public for free are those by the Transparency International, the World Bank, Global Integrity and Freedom House. Statistical data available from these sources has been used for the purpose of this paper. Corruption rankings from agencies such as the Business Environment Risk Intelligence, Economist Intelligence Unit, Gallup World Poll, Global Insight, Political and Economic Risk Consultancy, Ltd, etc. are additional sources available upon subscription. A list of website links providing additional information regarding these publications is shown in Table 2.

TABLE 2

WEBSITE ADDRESSES OF 'FOR PURCHASE' INDICES

\begin{tabular}{|l|l|l|}
\hline \multicolumn{1}{|c|}{ Index Name } & \multicolumn{1}{|c|}{ Source } & \multicolumn{1}{c|}{ Website Link } \\
\hline Financial Ethics Index & $\begin{array}{l}\text { Business Environment Risk } \\
\text { Intelligence }\end{array}$ & http://www.beri.com/qlm.asp \\
\hline Country Reports & Economist Intelligence Unit & http://countryanalysis.eiu.com/country reports \\
\hline Corruption Index & Gallup World Poll & $\begin{array}{l}\text { http://www.gallup.com/consulting/worldpoll/108073/Performance- } \\
\text { Indexes.aspx }\end{array}$ \\
\hline Sovereign Risk Ratings & Global Insight & http://www.globalinsight.com/SRS \\
\hline $\begin{array}{l}\text { 2008 Corruption in Asia } \\
\text { Cities Service }\end{array}$ & $\begin{array}{l}\text { Political and Economic Risk } \\
\text { Consultancy, Ltd }\end{array}$ & http://www.asiarisk.com/percrpts.html \\
\hline
\end{tabular}

We have compared the rankings of five indices that are freely available to the public: namely, the Corruption Perception Index, Bribe Payers Index, Global Integrity Index, Nations in Transit Index and Control of Corruption Index. We have compared the perfornance of OECD member and non-member countries against those presently not affiliated with the Convention.

\section{Transparency International}

Transparency International (TI) is a not-for-profit and non-partisan organization. It was founded in 1993 and was aimed at increasing public awareness about corruption globally. Other than regional chapters, it also has several local chapters globally. It has helped establish various statistical benchmarks for the measurement of corruption including the Corruption Perception Index (CPI), the Bribe Payers Index (BPI), the Global Corruption Barometer (GCB) and the Global Corruption Report(GCR). While the GCB and the GCR are a qualitative study of corruption, the CPI and the BPI use quantitative measures and have evolved into an effective tool for comparative analysis. 
TABLE 3

\begin{tabular}{|c|c|c|c|c|c|c|c|c|c|c|}
\hline & & & & 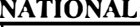 & & & & & & \\
\hline COUNTRY & 1998 & 1999 & 2000 & 2001 & 2002 & 2003 & 2004 & 2005 & 2006 & 2007 \\
\hline Possible Score Range* & $0-10.0$ & $0-10.0$ & 1.10.0 & $0-10.0$ & $0-10.0$ & $0-10.0$ & $0-10.0$ & $0-10.0$ & $0-10.0$ & 0-10.0 \\
\hline Score Range of Top $10 \%$ & $9.5-10.0$ & $9.4-10.0$ & $9.4-10.0$ & $9.4-9.9$ & $9.5-9.7$ & $9.5-9.6$ & $9.5-9.7$ & $9.6-9.7$ & 9.6 & 9.4 \\
\hline Score Range of Bottom $10 \%$ & $2.9 \cdot 3.3$ & $3.0-3.4$ & 3.3-3.5 & 3.5-3.7 & 2.8-3.6 & $2.5-3.6$ & 2.5-3.6 & $2.8-3.5$ & $2.9-3.3$ & $2.9-3.5$ \\
\hline Argentina & 3.0 & 3.0 & 3.5 & 3.5 & 2.8 & 2.5 & 2.5 & 2.8 & 2.9 & 2.9 \\
\hline Australia & 8.7 & 8.7 & 8.3 & 8.5 & 8.6 & 8.8 & 8.8 & 8.8 & 8.7 & 8.6 \\
\hline Austria & 7.5 & 7.6 & 7.7 & 7.8 & 7.8 & 8.0 & 8.4 & 8.7 & 8.6 & 8.1 \\
\hline Belgium & 5.4 & 5.3 & 6.1 & 6.6 & 7.1 & 7.6 & 7.5 & 7.4 & 7.3 & 7.1 \\
\hline Brazil & 4.0 & 4.1 & 3.9 & 4.0 & 4.0 & 3.9 & 3.9 & 3.7 & 3.3 & 3.5 \\
\hline Bulgaria & 2.9 & 3.3 & 3.5 & 3.9 & 4.0 & 3.9 & 4.1 & 4.0 & 4.0 & 4.1 \\
\hline Canada & 9.2 & 9.2 & 9.2 & 8.9 & 9.0 & 8.7 & 8.5 & 8.4 & 8.5 & 8.7 \\
\hline Chile & 6.8 & 6.9 & 7.4 & 7.5 & 7.5 & 7.4 & 7.4 & 7.3 & 7.3 & 7.0 \\
\hline Czech Republic & 4.8 & 4.6 & 4.3 & 3.9 & 3.7 & 3.9 & 4.2 & 4.3 & 4.8 & 5.2 \\
\hline Denmark & 10.0 & 10.0 & 9.8 & 9.5 & 9.5 & 9.5 & 9.5 & 9.5 & 9.5 & 9.4 \\
\hline Estonia & 5.7 & 5.7 & 5.7 & 5.6 & 5.6 & 5.5 & 6.0 & 6.4 & 6.7 & 6.5 \\
\hline Finland & 9.6 & 9.8 & 10.0 & 9.9 & 9.7 & 9.7 & 9.7 & 9.6 & 9.6 & 9.4 \\
\hline France & 6.7 & 6.6 & 6.7 & 6.7 & 6.3 & 6.9 & 7.1 & 7.5 & 7.4 & 7.3 \\
\hline Germany & 7.9 & 8.0 & 7.6 & 7.4 & 7.3 & 7.7 & 8.2 & 8.2 & 8.0 & 7.8 \\
\hline Greece & 4.9 & 4.9 & 4.9 & 4.2 & 4.2 & 4.3 & 4.3 & 4.3 & 4.4 & 4.6 \\
\hline Hungary & 5.0 & 5.2 & 5.2 & 5.3 & 4.9 & 4.8 & 4.8 & 5.0 & 5.2 & 5.3 \\
\hline Iceland & 9.3 & 9.2 & 9.1 & 9.2 & 9.4 & 9.6 & 9.5 & 9.7 & 9.6 & 9.2 \\
\hline Ireland & 8.2 & 7.7 & 7.2 & 7.5 & 6.9 & 7.5 & 7.5 & 7.4 & 7.4 & 7.5 \\
\hline Italy & 4.6 & 4.7 & 4.6 & 5.5 & 5.2 & 5.3 & 4.8 & 5.0 & 4.9 & 5.2 \\
\hline Japan & 5.8 & 6.0 & 6.4 & 7.1 & 7.1 & 7.0 & 6.9 & 7.3 & 7.6 & 7.5 \\
\hline Luxembourg & 8.7 & 8.8 & 8.6 & 8.7 & 9.0 & 8.7 & 8.4 & 8.5 & 8.6 & 8.4 \\
\hline Mexico & 3.3 & 3.4 & 3.3 & 3.7 & 3.6 & 3.6 & 3.6 & 3.5 & 3.3 & 3.5 \\
\hline Netherlands & 9.0 & 9.0 & 8.9 & 8.8 & 9.0 & 8.9 & 8.7 & 8.6 & 8.7 & 9.0 \\
\hline New Zealand & 9.4 & 9.4 & 9.4 & 9.4 & 9.5 & 9.5 & 9.6 & 9.6 & 9.6 & 9.4 \\
\hline Norway & 9.0 & 8.9 & 9.1 & 8.6 & 8.5 & 8.8 & 8.9 & 8.9 & 8.8 & 8.7 \\
\hline Poland & 4.6 & 4.2 & 4.1 & 4.1 & 4.0 & 3.6 & 3.5 & 3.4 & 3.7 & 4.2 \\
\hline Portugal & 6.5 & 6.7 & 6.4 & 6.3 & 6.3 & 6.6 & 6.3 & 6.5 & 6.6 & 6.5 \\
\hline Slovakia & 3.9 & 3.7 & 3.5 & 3.7 & 3.7 & 3.7 & 4.0 & 4.3 & 4.7 & 4.9 \\
\hline Slovenia & $\mathrm{n} / \mathrm{a}$ & 6.0 & 5.5 & 5.2 & 6.0 & 5.9 & 6.0 & 6.1 & 6.4 & 6.6 \\
\hline South Africa & 5.2 & 5.0 & 5.0 & 4.8 & 4.8 & 4.4 & 4.6 & 4.5 & 4.6 & 5.1 \\
\hline South Korea & 4.2 & 3.8 & 4.0 & 4.2 & 4.5 & 4.3 & 4.5 & 5.0 & 5.1 & 5.1 \\
\hline Spain & 6.1 & 6.6 & 7.0 & 7.0 & 7.1 & 6.9 & 7.1 & 7.0 & 6.8 & 6.7 \\
\hline Sweden & 9.5 & 9.4 & 9.4 & 9.0 & 9.3 & 9.3 & 9.2 & 9.2 & 9.2 & 9.3 \\
\hline Switzerland & 8.9 & 8.9 & 8.6 & 8.4 & 8.5 & 8.8 & 9.1 & 9.1 & 9.1 & 9.0 \\
\hline Turkey & 3.4 & 3.6 & 3.8 & 3.6 & 3.2 & 3.1 & 3.2 & 3.5 & 3.8 & 4.1 \\
\hline United Kingdom & 8.7 & 8.6 & 8.7 & 8.3 & 8.7 & 8.7 & 8.6 & 8.6 & 8.6 & 8.4 \\
\hline USA & 7.5 & 7.5 & 7.8 & 7.6 & 7.7 & 7.5 & 7.5 & 7.6 & 7.3 & 7.2 \\
\hline
\end{tabular}

* Possible Score Range: with 0 being the lowest and 10 the highest

Source: Surveys \& Indices - TI Corruption Perception Index,

http://www.transparency,org/policy_research/surveys_indices/cpi 


\section{Corruption Perception Index}

The Corruption Perception Index, one of the most prominent corruption measuring indices, ranks countries based on the perceived corruption amongst public officials and politicians within a country and focuses primarily on corruption in the public sector (Corruption Perception Index http://www.transparency.org/policy research/surveys indices/cpi). The index was first introduced in 1995 with comparative scores and rankings for 41 countries, including both OECD member and non-member countries. TI has consistently increased its coverage over the years and the latest CPI index includes data for 180 countries. For the purpose of measurement, it uses surveys on both resident and non-resident business people and country analysts. The 2007 index included data from 14 different surveys and uses a two-year average score methodology in order to reduce impact due to changes caused by random effects. While a change in absolute score may not be indicative of an improvement or a deterioration of actual performance, comparative evaluation amongst member countries provides valuable insight. Table 3 provides individual country scores since 1995:

As can be observed, Denmark, Finland and New Zealand have out-performed the rest and are consistently ranked within the top three. Meanwhile Argentina, Brazil, Mexico and Turkey make up the bottom 10\%. Among non-OECD members, Singapore is the only country to figure within the top $10 \%$ with scores ranging from $9.1-9.4$.

\section{Bribe Payers Index}

The Bribe Payers Index is another quantitative measurement tool of the TI. Scores are based on the propensity of firms from industrialized countries to bribe public officials in pre-selected emerging markets that carry on trade and receive investments from multinational companies (Surveys \& Indices http://www.transparency.org/policy_research/surveys indices/bpi).

TABLE 4

TRANSPARENCY INTERNATIONAL: BRIBE PAYERS INDEX

\begin{tabular}{|c|c|c|c|}
\hline Country & 1999 & 2002 & 2006 \\
\hline Possible Score Range* & $0-10$ & $0-10$ & $0-10$ \\
\hline Score Range of Top $10 \%$ & $8.1-8.3$ & $8.1-8.4$ & $7.6-7.8$ \\
\hline $\begin{array}{c}\text { Score Range of Bottom } \\
\mathbf{1 0 \%}\end{array}$ & 3.4-3.7 & $3.9-4.1$ & $5.83-5.94$ \\
\hline Australia & 8.1 & 8.5 & 7.6 \\
\hline Austria & 7.8 & 8.2 & 7.5 \\
\hline Belgium & 6.8 & 7.8 & 7.2 \\
\hline Brazil & $n / a$ & n/a & 5.7 \\
\hline Canada & 8.1 & 8.1 & 7.5 \\
\hline France & 5.2 & 5.5 & 6.5 \\
\hline Germany & 6.2 & 6.3 & 7.3 \\
\hline Italy & 3.7 & 4.1 & 5.9 \\
\hline Japan & 5.1 & 5.3 & 7.1 \\
\hline Mexico & $\mathrm{n} / \mathrm{a}$ & $n / a$ & 6.5 \\
\hline Netherlands & 7.4 & 7.8 & 7.3 \\
\hline Portugal & $n / a$ & $\mathrm{n} / \mathrm{a}$ & 6.5 \\
\hline South Africa & $\mathrm{n} / \mathrm{a}$ & $\mathrm{n} / \mathrm{a}$ & 5.6 \\
\hline South Korea & 3.4 & 3.9 & 5.8 \\
\hline Spain & 5.3 & 5.8 & 6.6 \\
\hline Sweden & 8.3 & 8.4 & 7.6 \\
\hline Switzerland & 7.7 & 8.4 & 7.8 \\
\hline Turkey & $\mathrm{n} / \mathrm{a}$ & $\mathrm{n} / \mathrm{a}$ & 5.2 \\
\hline UK & 7.2 & 6.9 & 7.4 \\
\hline US & 6.2 & 5.3 & 7.2 \\
\hline
\end{tabular}

* Possible Score Range: with 0 being the lowest and 10 the highest

Source: Surveys \& Indices - TI Bribe Payers Index

http://www.transparency.org/policy research/surveys indices/bpi 
The index rankings are based on surveys conducted in 15 of emerging economies conducting trade with multinational firms incorporated or headquartered in 21 leading exporting countries, those that collectively constitute the largest net total of global exports. The survey relates to the propensity of companies from these developed exporting countries to bribe public officials in the emerging markets. Since the survey is used only on a finite number of countries satisfying these criterion, rankings for all OECD member countries is not available.

Thus, the index helps evaluate the supply side of bribery. The first BPI was published in 1999 and contained rankings for 19 countries, while the most current index published in 2006 expanded coverage and now includes rankings for 30 countries. However, only 18 are members of the OECD Convention. The BPI consequently differs from the CPI since it seeks to measure bribe paid while conducting business overseas while the CPI attempts to measure the level of corruption perceived to exist domestically. The BPI through its survey has concluded that most countries perform better within OECD countries than in non-OECD emerging economies.

As is evident from table 4, Canada and Sweden consistently rank among the top two. Although absolute scores for Italy and South Korea have shown yearly improvement, analysis provided by TI contradicts this perceived improvement and the two countries continue to be the worst performers in the index. While no non-OECD country falls within the top $10 \%$, Singapore with scores ranging between $5.7-7.8$ and the UAE with the only available score of 6.62 for 2006, have recorded better than average scores of all OECD countries.

\section{The World Bank}

Amongst the multitude of data published by the World Bank one of the more prominent ones is the Worldwide Governance Indicator (Kauffman, Kraay and Mastruzzi - Governance Matters VI: Aggregate and Individual Governanace Indicators: http://info.worldbank.org/governance/wgi2007/). It provides scores for over 200 countries and covers six aspects of governance including accountability, political stability, government effectiveness, regulatory quality, rule of law and control of comuption. Although data available dates back to 1996, it had been sporadic until 2002. The World Bank has released data annually since 2002 with the most recent available numbers corresponding to 2006.

The Control of Comuption index, a sub-part of the governance indicator, uses data from 22 individual agencies, including public, non-government organizations as well as private research institutes. It incorporates scores from the Global Integrity Index as well as some by Freedom House. The methodology consists of surveys of firms and individuals in an attempt to measure the level of corruption within the public sector. The sources used address comuption within the political system particularly in the form of vested private interests, illegal payments to public officials, anti-comuption legislation and its enforceability, use of public funds, etc. The index has consistently increased its coverage of countries from 154 in 1996 to 214 in 2006 and has always included scores and rankings for all OECD member countries. Also, the latest index uses 33 data sources. Hence a change in measurement criteria for one will lead to an overall score revision. Similarly, some criteria have been revised yearly, making yearly performance comparison inaccurate. However, the index is useful for comparative country-wise analysis within any given year.

Similar to the CPI, Denmark, Finland and New Zealand have year after year out-performed others to secure the top three ranks while Argentina, Bulgaria, Brazil and Mexico have all reported the lowest scores. Singapore is once again the only non-OECD country with scores similar to the top 3 countries. 
WORLD BANK: CONTROL OF CORRUPTION INDEX

\begin{tabular}{|c|c|c|c|c|c|c|c|c|c|}
\hline COUNTRIES & 1996 & 1998 & 2000 & 2002 & 2003 & 2004 & 2005 & 2006 & 2007 \\
\hline Possible Score Range* & $(-2.5)-2.5$ & $(-2.5)-2.5$ & $(-2.5)-2,5$ & $(-2.5)-2.5$ & $(-2.5)-2.5$ & $(-2.5)-2.5$ & $(-2.5)-2.5$ & $(-2.5)-2.5$ & $(-2.5)-2.5$ \\
\hline Score Range of Top $10 \%$ & 2.29-2.30 & $2.21-2.24$ & 2.18-2.34 & 2.27 .2 .46 & $2.34-2.42$ & $2.37-2.46$ & $2.24-2.49$ & $2.40-2.58$ & $2.37-2.60$ \\
\hline Score Range of Bottom $10 \%$ & $(-0.76)-(-0.18)$ & $(-0.53)-(-0.17)$ & $(-0.37)-(-0.23)$ & $(-0.70)-(-0.26)$ & $(-0.43)-(-0.19)$ & $(-0.45)-(-0.16)$ & $(-0.41)-(-0.23)$ & $(-0.40)-(-0.20)$ & $(-0.45)-(-0.22)$ \\
\hline Argentina & -0.18 & -0.15 & -0.29 & -0.70 & -0.43 & -0.41 & -0.41 & -0.40 & -0.45 \\
\hline Australia & 1.85 & 1.97 & 1.96 & 1.92 & 2.03 & 2.09 & 1.97 & 2.00 & 2.05 \\
\hline Austria & 1.98 & 1.92 & 1.93 & 2.04 & 2.09 & 2.10 & 1.98 & 2.00 & 2.02 \\
\hline Belgium & 1.40 & 1.42 & 1.55 & 1.62 & 1.55 & 1.51 & 1.46 & 1.41 & 1.45 \\
\hline Brazil & -0.18 & 0.04 & 0.04 & -0.14 & 0.05 & 0.00 & -0.23 & -0.20 & 0.12 \\
\hline Bulgaria & -0.76 & -0.33 & -0.23 & -0.14 & -0.06 & 0.10 & 0.01 & -0.09 & -0.22 \\
\hline Canada & 2.22 & 2.06 & 2.02 & 2.05 & 2.06 & 1.92 & 1.92 & 1.95 & 2.09 \\
\hline Chile & 1.29 & 1.27 & 1.45 & 1.48 & 1.21 & 1.41 & 1.34 & 1.34 & 1.35 \\
\hline Czech Republic & 0.58 & 0.45 & 0.29 & 0.35 & 0.40 & 0.36 & 0.44 & 0.32 & 0.26 \\
\hline Denmark & 2.29 & 2.19 & 2.18 & 2.27 & 2.31 & 2.37 & 2.24 & 2.40 & 2.42 \\
\hline Estonia & -0.02 & 0.42 & 0.62 & 0.69 & 0.80 & 0.94 & 0.91 & 0.90 & 0.94 \\
\hline Finland & 2.30 & 2.24 & 2.34 & 2.46 & 2.42 & 2.46 & 2.40 & 2.58 & 2.59 \\
\hline France & 1.45 & 1.51 & 1.50 & 1.37 & 1.47 & 1.44 & 1.40 & 1.46 & 1.32 \\
\hline Germany & 2.09 & 2.08 & 2.00 & 1.99 & 1.99 & 1.91 & 1.92 & 1.84 & 1.80 \\
\hline Greece & 0.38 & 0.69 & 0.73 & 0.55 & 0.57 & 0.57 & 0.40 & 0.40 & 0.28 \\
\hline Hungary & 0.63 & 0.67 & 0.69 & 0.58 & 0.62 & 0.68 & 0.61 & 0.57 & 0.44 \\
\hline Iceland & 1.82 & 1.92 & 2.21 & 2.22 & 2.39 & 2.35 & 2.49 & 2.46 & 2.60 \\
\hline Ireland & 1.85 & 1.74 & 1.59 & 1.61 & 1.67 & 1.51 & 1.69 & 1.70 & 1.75 \\
\hline Italy & 0.49 & 0.69 & 0.98 & 0.77 & 0.75 & 0.61 & 0.39 & 0.41 & 0.45 \\
\hline Japan & 1.14 & 1.31 & 1.35 & 1.05 & 1.19 & 1.19 & 1.25 & 1.35 & 1.20 \\
\hline Luxembourg & 1.95 & 1.99 & 2.05 & 2.21 & 1.89 & 2.01 & 1.84 & 2.03 & 2.27 \\
\hline Mexico & -0.39 & -0.53 & -0.37 & -0.26 & -0.19 & -0.35 & -0.39 & -0.34 & -0.35 \\
\hline Netherlands & 2.22 & 2.18 & 2.18 & 2.18 & 2.08 & 2.02 & 1.99 & 2.06 & 2.25 \\
\hline New Zealand & 2.29 & 2.20 & 2.16 & 2.28 & 2.34 & 2.39 & 2.24 & 2.34 & 2.36 \\
\hline Norway & 2.30 & 2.22 & 2.14 & 2.18 & 2.13 & 2.03 & 2.05 & 2.14 & 2.09 \\
\hline Poland & 0.39 & 0.60 & 0.51 & 0.34 & 0.40 & 0.20 & 0.19 & 0.19 & 0.14 \\
\hline Portugal & 1.57 & 1.31 & 1.24 & 1.35 & 1.29 & 1.22 & 1.15 & 1.09 & 1.13 \\
\hline Slovakia & 0.40 & -0.03 & 0.24 & 0.10 & 0.34 & 0.45 & 0.45 & 0.37 & 0.28 \\
\hline Slovenia & 1.05 & 0.94 & 0.76 & 0.79 & 0.84 & 1.00 & 0.87 & 0.94 & 0.90 \\
\hline South Africa & 0.62 & 0.64 & 0.56 & 0.35 & 0.35 & 0.44 & 0.54 & 0.44 & 0.32 \\
\hline South Korea & 0.32 & 0.10 & 0.19 & 0.37 & 0.29 & 0.29 & 0.50 & 0.29 & 0.36 \\
\hline Spain & 1.08 & 1.38 & 1.43 & 1.42 & 1.46 & 1.41 & 1.34 & 1.16 & 1.16 \\
\hline Sweden & 2.27 & 2.21 & 2.23 & 2.25 & 2.21 & 2.17 & 2.10 & 2.22 & 2.37 \\
\hline Switzerland & 2.20 & 2.17 & 2.13 & 2.17 & 2.17 & 2.10 & 2.12 & 2.20 & 2.32 \\
\hline Turkey & 0.01 & -0.17 & -0.20 & -0.43 & -0.24 & -0.16 & -0.05 & 0.02 & 0.04 \\
\hline United Kingdom & 2.21 & 2.16 & 2.13 & 2.10 & 2.08 & 1.99 & 1.93 & 1.90 & 1.89 \\
\hline USA & 1.75 & 1.75 & 1.77 & 1.88 & 1.74 & 1.75 & 1.56 & 1.34 & 1.44 \\
\hline
\end{tabular}

* Possible Score Range: with -2.5 being the lowest and 2.5 the highest

Source : Worldwide Governance Indicators, http://info.worldbank.org/governance/wgi/sc_country.asp 


\section{Global Integrity}

Global Integrity is an independent not-for-profit non-governmental international information provider. It was founded in 1999 and has helped establish the Global Integrity Index (GII), a quantitative index with individual country ratings. The GII currently provides data for the years 2004, 2006 and 2007 (Global Integrity Index 2007: http://report.globalintegrity.org/globalIndex.cfm). It uses an average of 300 data sources to arrive at its ratings, which analyze the corruption environment within a country. The organization also publishes the Global Integrity Report, a qualitative analysis of governance and anti-corruption trends worldwide. Based on the data gathered for 2007, it has concluded that the US, Canada, France, Japan and Italy - countries tracked by it and also OECD member countries, continue to be plagued with corruption similar to those of developing countries due to poor regulation over political financing.

While the index includes 48 countries, it has attempted to maintain a geographical balance by including countries within all sub-continents. It includes 12 from Sub-Saharan Africa, 4 from East and Southeast Asia, 3 from Pacific, 13 from Europe, 6 from Latin America, 4 from Middle East and North Africa, 11 from South and Central Asia and 2 from North America. It has thus maintained a regional diversification. Of these 48 countries, 35 percent are ranked as free, 47 percent as partly free and 18 percent as not free with respect to civil liberties and basic freedom. The index has tried to maintain this ratio of freedom and hence the composition of countries comprising the index has changed yearly. Hence scores for some countries is not available for all years. Additionally, since a vast majority of OECD members are European countries and given that only 13 from that region have been included in this index, only 7 European OECD countries are present in the Global Integrity Index. Altogether, only 14 OECD Convention members are in the entire index.

The index itself ranks the countries based on three main parameters - legal framework within each country, actual implementation and the implementation gap. This assigned score is an aggregation of integrity indicators, which are organized into 6 governance categories, including public information and media, elections, government accountability, administration and civil service, oversight and regulation, and anti-corruption and rule of law. These 6 categories are further divided into 23 sub-categories. Anti-corruption and rule of law forms a major part of the index and comprises of the following four subcategories - analysis of the anti-corruption law, anti-corruption agency, rule of law and law enforcement.

TABLE 6

GLOBAL INTEGRITY: GLOBAL INTEGRITY INDEX

\begin{tabular}{|c|c|c|c|}
\hline COUNTRIES & $\mathbf{2 0 0 4}$ & $\mathbf{2 0 0 6}$ & $\mathbf{2 0 0 7}$ \\
\hline Possible Score Range* & $\mathbf{0 - 1 0 0}$ & $\mathbf{0 - 1 0 0}$ & $\mathbf{8 1 0 0}$ \\
\hline Score Range of Top 10\% & $\mathbf{8 6 - 8 8}$ & $\mathbf{8 1 - 8 7}$ & $\mathbf{5 3}$ \\
\hline Score Range of Bottom 10\% & $\mathbf{6 4 - 7 1}$ & $\mathbf{5 7 - 6 5}$ & $\mathbf{7 5}$ \\
\hline Argentina & $\mathbf{7 8}$ & $\mathbf{7 9}$ & $\mathrm{n} / \mathrm{a}$ \\
\hline Australia & 83 & $\mathrm{n} / \mathrm{a}$ & $\mathrm{n} / \mathrm{a}$ \\
\hline Brazil & 75 & $\mathbf{7 3}$ & 87 \\
\hline Bulgaria & $\mathrm{n} / \mathrm{a}$ & 80 & 81 \\
\hline Canada & $\mathrm{n} / \mathrm{a}$ & $\mathrm{n} / \mathrm{a}$ & 53 \\
\hline Egypt & $\mathrm{n} / \mathrm{a}$ & 57 & $\mathbf{7 8}$ \\
\hline France & $\mathrm{n} / \mathrm{a}$ & $\mathrm{n} / \mathrm{a}$ & $\mathrm{n} / \mathrm{a}$ \\
\hline Germany & 83 & $\mathrm{n} / \mathrm{a}$ & 81 \\
\hline Italy & 83 & $\mathrm{n} / \mathrm{a}$ & 81 \\
\hline Japan & 71 & $\mathrm{n} / \mathrm{a}$ & 63 \\
\hline Mexico & 75 & 65 & $\mathrm{n} / \mathrm{a}$ \\
\hline Portugal & 86 & $\mathrm{n} / \mathrm{a}$ & $\mathrm{n} / \mathrm{a}$ \\
\hline South Africa & 81 & 81 & 81 \\
\hline Spain & $\mathrm{n} / \mathrm{a}$ & $\mathrm{n} / \mathrm{a}$ & $\mathbf{7 1}$ \\
\hline United States & 64 & $\mathrm{n} / \mathrm{a}$ & 87 \\
\hline
\end{tabular}

* Possible Score Range: with 0 being the lowest and 100 the highest

Source: Global Integrity Index 2007

http://www.globalintegrity.org/data/downloads.cfm 
Since the inception of the index, Global Integrity has changed its methodology as well as the confidence interval used for data aggregation. Hence as noted earlier in this paper, a yearly comparison of scores might be inaccurate. However, the US scores were the highest for 2004 and 2006 while Egypt and Turkey scored poorly and are amongst the bottom two, as seen in Table 6.

\section{Freedom House}

Freedom House is a not-for-profit non-partisan organization and provides information regarding the status of independence worldwide. It was founded in 1941 and presently has four annual surveys - Freedom in the World, Nations in Transit, Freedom of the Press and Countries at the Crossroads (www.freedomhouse.org). While the first two offer country wise quantitative scores, Freedom of the Press provides a regional overview and Countries at Crossroads provides a qualitative description of governance indicators.

Nations in Transit measures reform in central-eastern Europe and Eurasia and as a result only 7 OECD countries fall within the purview of this index. It measures progress across 7 parameters -national and local democratic governance, electoral process, civil society, independent media, judicial framework and corruption. With respect to the corruption ratings, the index seeks to measure corruption perception, private interests of public officials, laws on financial disclosure, conflicts of interest and effectiveness of legislative implementation. The corruption ratings currently includes data for 30 countries, 7 of which are OECD members. Annual scores and rankings are available from 2000 through 2006. In addition to the statistical data, the index also provides a qualitative analysis such as country-wise and regional summaries in political and judicial reforms.

TABLE 7

FREEDOM HOUSE: NATIONS IN TRANSIT

\begin{tabular}{|c|c|c|c|c|c|c|c|c|}
\hline COUNTRY & $\mathbf{1 9 9 9 - 2 0 0 0}$ & $\mathbf{2 0 0 1}$ & $\mathbf{2 0 0 2}$ & $\mathbf{2 0 0 3}$ & $\mathbf{2 0 0 4}$ & $\mathbf{2 0 0 5}$ & $\mathbf{2 0 0 6}$ & $\mathbf{2 0 0 7}$ \\
\hline Possible Score Range & $\mathbf{1 - 7}$ & $\mathbf{1 - 7}$ & $\mathbf{1 - 7}$ & $\mathbf{1 - 7}$ & $\mathbf{1 - 7}$ & $\mathbf{1 - 7}$ & $\mathbf{1 - 7}$ & $\mathbf{1 - 7}$ \\
\hline Score Range of Top 10\% & $\mathbf{4 . 7 5}$ & $\mathbf{4 . 7 5}$ & $\mathbf{4 . 5 0}$ & $\mathbf{4 . 2 5}$ & $\mathbf{4 . 2 5}$ & $\mathbf{4 . 0 0}$ & $\mathbf{3 . 7 5}$ & $\mathbf{3 . 7 5}$ \\
\hline Score Range of Bottom 10\% & $\mathbf{2 . 0 0}$ & $\mathbf{2 . 0 0}$ & $\mathbf{2 . 0 0}$ & $\mathbf{2 . 0 0}$ & $\mathbf{2 . 0 0}$ & $\mathbf{2 . 0 0}$ & $\mathbf{2 . 2 5}$ & $\mathbf{2 . 2 5}$ \\
\hline Bulgaria & 4.75 & 4.75 & 4.50 & 4.25 & 4.25 & 4.00 & 3.75 & 3.75 \\
\hline Czech Republic & 3.25 & 3.75 & 3.75 & 3.50 & 3.50 & 3.50 & 3.50 & 3.50 \\
\hline Estonia & 3.25 & 2.75 & 2.50 & 2.50 & 2.50 & 2.50 & 2.50 & 2.50 \\
\hline Hungary & 2.50 & 3.00 & 3.00 & 2.75 & 2.75 & 2.75 & 3.00 & 3.00 \\
\hline Poland & 2.25 & 2.25 & 2.25 & 2.50 & 2.50 & 3.00 & 3.25 & 3.00 \\
\hline Slovakia & 3.75 & 3.75 & 3.25 & 3.25 & 3.25 & 3.00 & 3.00 & 3.25 \\
\hline Slovenia & 2.00 & 2.00 & 2.00 & 2.00 & 2.00 & 2.00 & 2.25 & 2.25 \\
\hline
\end{tabular}

* Possible Score Range: with 0 being the lowest and 7 the highest

Source: Freedom House- Nations in Transit, Corruption Ratings 2006

http://www.freedomhouse.org/template.cfm?page $=424 \& y e a r=2007$

The 7 OECD Convention members included in this index are otherwise amongst the lowest ranked in all other indices. In this index as well, they continue to perform worse than others in the region. Hence, most nonOECD countries in the index fell within the top $10 \%$ of OECD members, while the remaining performed better than Slovenia, the lowest scorer OECD Convention member.

\section{Comparisons With OECD Non-Member Countries}

While most countries with a high anti-corruption ranking are members of the OECD and are thus subject to the provisions as prescribed by the OECD Anti-Bribery Convention, we have attempted to compare this performance against non-members. We have used the 5 indices as mentioned above for the purpose of this study. We have used two parameters for this purpose, (i) countries not affiliated with the convention with a score greater than the country with the lowest score within the top-ten members and (ii) non-affiliated countries with a score greater than the bottom-ten member countries. 
It was observed that Singapore was the only country to consistently record a score within the top $10 \%$ in most indices. While there are host of countries that have scored above the bottom- $10 \%$, some have been consistent while others have been sporadic. Among the out-performers are Hong Kong, Israel and the United Arab Emirates, countries that have recorded a near constant score within the $90^{\text {th }}$ percentile on most indices.

Of the five indices, the CPI and the Control of Corruption Index are more exhaustive in their coverage and thus include a higher number of non-OECD countries. While the CPI covers 154 countries, the World Bank Control of Corruption Index tracks in excess of 200 countries. As a result, these indices also include a higher percentage of non-OECD countries faring better than the OECD countries. Countries such as Bahrain, Botswana, Malaysia, Mauritius, Oman, Qatar, Taiwan and Uruguay although not included in all indices, have consistently reported better scores than the bottom $10 \%$ on the CPI and Control of Corruption.

Also, while the Freedom House Nations in Transit index is narrow in its coverage, it nevertheless provides a basis for regional comparisons. Romania, Latvia and Ukraine have reported scores of greater than the bottom $10 \%$ in at least two of the five indices.

Tables 8 \& Table 9 show a list of countries reporting scores within the top $10 \%$ or better than the lowest $10 \%$ in most indices on a consistent yearly basis:

This comparison shows that some countries, although not part of the OECD Convention, have implemented good anti-corruption laws and procedures. An inclusion of these countries within the OECD Convention would help further enhance co-operation and exchange of information between countries.

\section{PHASE II OF THE OECD CONVENTION}

During its Phase Two review of the implementation of the OECD regulations by member countries, the OECD has published country-wise findings (Country Reports on the Implementation of OECD Anti-Bribery Convention and the Revised 1997 Recommendation: www.oecd.org). While some measures adopted are indicative of a progress in anti-corruption regulations, the review has found a few recurring problem areas that require additional attention.

Key amongst them remains the lack of liability for legal persons. Presently, while most countries have criminal and legal sanctions against natural persons, legal entities such as corporations cannot be held criminally liable for committing acts of foreign bribery. The OECD has found this to be a cause for procedural deficiency in investigation and prosecution. Both of these present potential challenges, especially for countries with a less than average score such as Argentina, Bulgaria, Czech Republic, Chile, Slovakia and Turkey. Additionally, the review found that while prosecution of domestic bribery cases has gained importance within the countries, a lack of awareness of foreign bribery offences, including tax deductibility of foreign bribes, within both private and public sectors continues to remain a challenge. In some instances this includes a lack of activity, policies and efforts by law enforcement agencies as well as the by the respective local govemment for e.g. Brazil, Czech Republic, Chile, Estonia, Mexico, Poland, Slovakia, Turkey. The review commission also highlighted specific programs detrimental to the long-term fight against comuption (Country Reports on the Implementation of the OECD Anti-Bribery Convention and the 1997 Revised Recommendation - Phase 2 Country Reports http://www.oecd.org/document/24/0,3343,en_2649 $34859 \quad 1933144 \quad 1 \quad 1 \quad 1 \quad 1,00$ html\#phase 2). It emphasized concerns regarding Poland and Slovakia, wherein there exists an impunity provision that provides an offender immunity for notifying authorities of a foreign bribery offense. 


\begin{tabular}{|c|c|c|c|c|c|}
\hline \multicolumn{6}{|c|}{ PERFORMANCE OF NON-OECD COUNTRIES } \\
\hline \multicolumn{6}{|c|}{ TABLE 8} \\
\hline $\begin{array}{l}\text { COUNTRIES BETTER THAN BOTTOM } 10 \% \text { OF } \\
\text { OECD MEMBERS }\end{array}$ & & & $\therefore$ & & \\
\hline Countries Within Top 10\% & Bribe Payers Index & $\begin{array}{c}\text { Control of } \\
\text { Corruption Index }\end{array}$ & $\begin{array}{c}\text { Corruption } \\
\text { Perception Index }\end{array}$ & $\begin{array}{l}\text { Global Integrity } \\
\text { Index }\end{array}$ & Nations in Transit \\
\hline Singapore & No & Yes & Yes & No & $\mathrm{n} / \mathrm{a}$ \\
\hline \multicolumn{6}{|c|}{ PERFORMANCE OF NON-OECD COUNTRIES } \\
\hline \multicolumn{6}{|c|}{ TABLE 9} \\
\hline Countries Above Bottom 10\% & Bribe Payers Index & $\begin{array}{c}\text { Control of } \\
\text { Corruption Index }\end{array}$ & $\begin{array}{c}\text { Corruption } \\
\text { Perception Index }\end{array}$ & $\begin{array}{l}\text { Global Integrity } \\
\text { Index }\end{array}$ & Nations in Transit \\
\hline Bahrain & No & Yes & Yes & No & $\mathrm{n} / \mathrm{a}$ \\
\hline Botswana & No & Yes & Yes & No & $\mathrm{n} / \mathrm{a}$ \\
\hline Georgia & No & No & No & Yes & Yes \\
\hline Hong Kong & Yes & Yes & Yes & No & $\mathrm{n} / \mathrm{a}$ \\
\hline Israel & Yes & Yes & Yes & Yes & $\mathrm{n} / \mathrm{a}$ \\
\hline Latvia & No & No & No & Yes & Yes \\
\hline Malaysia & No & Yes & Yes & No & $\mathrm{n} / \mathrm{a}$ \\
\hline Mauritius & No & Yes & Yes & No & $\mathrm{n} / \mathrm{a}$ \\
\hline Oman & No & Yes & Yes & No & $\mathrm{n} / \mathrm{a}$ \\
\hline Qatar & No & Yes & Yes & No & $\mathrm{n} / \mathrm{a}$ \\
\hline Romania & No & No & No & Yes & Yes \\
\hline Singapore & Yes & Yes & Yes & No & $\mathrm{n} / \mathrm{a}$ \\
\hline Taiwan & No & Yes & Yes & No & $\mathrm{n} / \mathrm{a}$ \\
\hline Ukraine & No & No & Yes & Yes & Yes \\
\hline United Arab Emirates & Yes & Yes & Yes & No & $\mathrm{n} / \mathrm{a}$ \\
\hline Uruguay & No & Yes & Yes & No & $\mathrm{n} / \mathrm{a}$ \\
\hline
\end{tabular}

n/a: Since the Nations in Transit Index rates countries within a specific region, it is not applicable to all countries in this table 


\section{CONCLUSION}

Although the United States initially was the leader in the passage of anti-bribery legislation with the passage of the Foreign Corrupt Practices Act of 1977 the importance of anti-bribery legislation an international basis is evidenced by the OECD. While most auditing textbooks only discuss the FCPA we believe a discussion of the OECD is important as the US adopts IFRS and international auditing standards. In addition to providing an overview of the FCPA and OECD, this paper extends prior literature by providing a discussion of Phase II of the OECD. We also examined how OECD countries and non OECD countries are perceived using five publicly available indices that measure comuption. Our findings show that Denmark, Finland and New Zealand are the highest ranked OECD countries (low corruption) while Argentina, Bulgaria, Brazil and Mexico are the low ranked (higher corruption) OECD. Singapore was the one non-OECD country that received high scores across the indices. These results suggest that more work is necessary in the low ranked countries and that the OECD should consider inviting Singapore into the OECD.

\section{AUTHOR INFORMATION}

Bina Menon graduated from Marquette University with an M.S. in Accounting in August 2008. She has a B.S. in Commerce from the University of Mumbai, India and was previously employed with Morgan Stanley in Wisconsin. She is presently a Tax Associate at PricewaterhouseCoopers in the Milwaukee Office.

Dr. Michael D. Akers, CPA, CIA, CMA, CFE, CBM is the Charles T. Horngren Professor of Accounting and Chair, Department of Accounting. He earned his doctoral degree at the University of Mississippi and his MBA at the University of Louisville. In addition to serving on the editorial advisory board of two journals, he has authored more than 50 articles in academic and professional journals. He currently serves on the Audit Committee and Board of Directors of two publicly traded companies.

\section{REFERENCES}

1. 2007 Global Integrity Index. http://report.globalintegrity.org/globallndex.cfm

2. Apke, Thomas M, Managerial Auditing Journal, 2001. The impact of OECD Convention Anti-bribery Provisions on International Companies

3. Bennet, Iris, National Law Journal, 2008. Corruption Remains a Business Risk

4. Country Reports on the Implementation of the OECD Anti-Bribery Convention and the 1997 Revised Recommendation - Phase 2 Country Reports

http://www.oecd.org/document/24/0,3343,en $2649 \quad 34859 \quad 1933144 \quad 1 \quad 1 \quad 1 \quad 1,00$. html\#phase 2

5. Foreign Corrupt Practices, House of Representatives, December 6, $1977-95^{\text {th }}$ Congress, $1^{\text {st }}$ Session, Report No. 94-831. http://www.usdoj.gov/criminal/fraud/fcpa/history/1977/cornuptrpt.html

6. Foreign Corrupt Practices and Domestic and Foreign Investment Improved Disclosure Acts of 1977, Introduced in Senate, May 2 (legislative day March 28), $1977-95^{\text {th }}$ Congress, $1^{\text {st }}$ Session, Report No.95114: http://www.usdoj.gov/criminal/fraud/fcpa/history/1977/senaterpt.html

7. Foreign Press Center Briefing - June 29, 2001 : http://www.fpc.state.gov/fpc/7490.htm

8. Freedom House: Nations in Transit. www.freedomhouse.org

9. Gerlach, Paul V., Testimony on September 10, 1998: The international Anti-Bribery and Fair Competition Act of 1988: http://www.sec.gov/news/testimony/testarchive/1998/tsty1 198.txt

10. Governance Matters VI: Aggregate and Individual Governance Indicators, 1996-2006 by Daniel Kaufmann, Aart Kraay and Massimo Mastruzzi: http://info.worldbank.org/governance/wgi2007/

11. International Agreements, OECD Convention http://www.fcpaenforcement.com/documents/document detail.asp?ID=713\&PAGE=4

12. International Anti-Bribery Act of 1998 - 1998 Amendments http://www.justice.gov/criminal/fraud/fcpa/history/1998/amends/leghistory.html

13. Pacini, Swingen, and Rogers, Managerial Auditing Journal, 2002. The OECD Convention and Bribery in International Business Transactions: Implications for Auditors

14. Santangelo, Stein, and Jacobs, The Journal of Investment Compliance, 2007. The Foreign Cornupt Practices Act: Recent Cases and Enforcement Trends 
15. Seitzinger, Michael V., CRS Report to Congress-FCPA, March 1999. http://www.fas.org/irp/crs/Crsfcpa.htm http://www.lectlaw.com/files/bur21.htm

16. Surveys \& Indices, TI Corruption Perception Index. http://www.transparency.org/policy research/surveys indices/cpi

17. Surveys \& Indices, TI Bribe Payers Index. http://www.transparency.org/policy research/surveys indices/bpi

18. Trade and Competitiveness Act, Foreign Corrupt Practices Amendment of 1988 http://www.usdoj.gov/criminal/fraud/fcpa/history/1988/tradeact.html

19. Unlawful Corporate Payments Act of 1977, Introduced in the House of Representatives, September 28, $1977-95^{\text {th }}$ Congress, $1^{\text {st }}$ Session, Report No. 95-640

http://www.usdoj.gov/criminal/fraud/fcpa/history/1977/houseprt.html

\section{NOTES}

